\title{
Hubungan Lifestyle Without Tobacco Terhadap Perkembangan Anak Usia Dini
}

\author{
Dewi Sartika $^{\natural}$, Hadi Pajarianto', Wahyuni Ulpi ${ }^{1}$, Andi Sitti Umrah ${ }^{2}$, Sri Rahayu Amri ${ }^{2}$ \\ Pendidikan Guru Pendidikan Anak Usia Dini, Universitas Muhammadiyah Palopo, \\ Indonesia(1); Kebidanan, Universitas Muhammadiyah Palopo, Indonesia(2) \\ DOI: $\underline{10.31004 / o b s e s i . v 6 i 4.2358}$
}

\begin{abstract}
Abstrak
Rokok dapat menyebabkan berbagai penyakit seperti penyakit jantung dan pembuluh darah, stroke, kanker paru-paru dan kanker mulut, bahkan mengancam perkembangan anak usia dini. Pertanyaan penelitian ini adalah apakah Lifestyle Without Tobacco memiliki hubungan dengan perkembangan anak usia dini. Jenis penelitian ini adalah kuantitatif dengan desain korelasional. Responden sebanyak 40 orang dari desa Bone Bone, dan Salukanan sebagai kontrol. Hasil analisis data ditemukan adanya perbedaan perkembangan anak usia dini pada kawasan yang menerapkan kawasan tanpa asap rokok dan desa yang tidak menerapkan kawasan tanpa asap rokok. Berdasarkan hasil uji regresi logistik sederhana diperoleh bahwa nilai $\operatorname{Exp}$ (B) 56,0 dan nilai $\rho=0,000$. Novelty penelitian ini membuktikan bahwa anak usia dini yang orang tuanya tidak merokok memiliki perkembangan yang lebih baik dibandingkan dengan yang orang tuanya merokok atau daerah dengan tingkat prevalensi perokok tinggi. Secara praktis menjadi rekomendasi terhadap terciptanya lingkungan anak usia dini yang bebas asap rokok.
\end{abstract}

Kata Kunci: lifestyle without tobacco; perkembangan; usia dini; moral; agama

\begin{abstract}
Cigarettes can cause various diseases such as heart and blood vessel disease, stroke, lung cancer and oral cancer, and even threaten the development of early childhood. This study aims to reveal the data regarding the impact of Lifestyle Without Tobacco on early childhood development. This research is quantitative with a descriptive correlational design. There were 40 Respondents from Bone Bone village, and Salukanan as a control. The results of data analysis shows that there are differences of early childhood development in areas that applied smoke-free areas and villages that did not apply smoke-free areas. Based on the results of the simple logistic regression test, it is obtained that the value of $\operatorname{Exp}(B)$ is 56.0 and the value of $\rho$ $=0.000$. The novelty of this study proves that early childhood whose parents do not smoke are developing better than those whose parents smoke or areas with high smoking prevalence rates. Practically, it is a recommendation to create a smoke-free early childhood environment.
\end{abstract}

Keywords: lifestyle without tobacco; development; early childhood, moral; religion

Copyright (c) 2022 Dewi Sartika, et al.

$\bowtie$ Corresponding author :

Email Address: hadipajarianto@umpalopo.ac.id (kota Palopo-Sulawesi Selatan)

Received 1 November 2021, Accepted 15 February 2022, Published 23 February 2022

PENDAHULUAN 
Rokok akan menghasilkan asap yang sangat berbahaya bagi kesehatan perokok itu sendiri sebagai perokok aktif, maupun di lingkungan sekitarnya sebagai perokok pasif. Asap rokok pada dasarnya terdiri dari asap asli yang mengandung $25 \%$ zat berbahaya dan asap sekunder yang mengandung $75 \%$ zat berbahaya. Asap rokok menghirup setengah dari 75 yang berbahaya dan setengah dari asap yang dihembuskannya. Tembakau mengandung 4.000 bahan kimia beracun, lebih dari 69 di antaranya bersifat karsinogenik. Oleh karena itu, tembakau dan asap tembakau yang terkontaminasi lingkungan dapat berbahaya bagi kesehatan. Tembakau juga menurunkan kesuburan, perkembangan fisik janin, menurunkan IQ (intelectual questiont), melemahnya kekebalan bayi, dan peningkatan angka kematian (Hasibuan \& Harahap, 2019).

Organisasi Kesehatan Dunia (WHO) merilis bahwa merokok menjadi masalah kesehatan masyarakat yang signifikan di seluruh dunia selama dekade terakhir. Indonesia memiliki 10 metrik PHBS termasuk perawatan kesuburan, ASI eksklusif, jaminan kesehatan (JPK), berhenti merokok, aktivitas fisik harian, asupan buah dan sayur setiap hari, air bersih, toilet yang mudah diakses, dan kepatuhan terhadap peraturan yang diberikan oleh tenaga kesehatan. Ini adalah rumah sejumlah penghuni, dan lantai rumah bukan tanah (Munthe, 2018). Indonesia memiliki populasi perokok terbesar ketiga setelah China dan India. Indonesia memiliki perokok aktif terbanyak, dengan prevalensi $67 \%$ (57,6 juta) pada pria dan 2,7\% (2,3 juta) pada wanita. Angka kematian akibat penyakit tidak menular yang berhubungan dengan merokok diperkirakan akan terus meningkat, dan sedikitnya 5 juta orang di seluruh dunia meninggal setiap tahun akibat merokok. Dikhawatirkan angka ini akan mencapai 10 juta per tahun pada tahun 2030, dimana 70\% di antaranya berada di negara berkembang, belum termasuk jumlah anak yang menjadi perokok pasif (Evi Hasnita, Nurhayati, 2021; Muhammad Amin Rais, 2021).

Pada penelitian terdahulu menemukan ayah perokok menyebabkan terjadinya dampak negatif pada anak-anaknya, baik dampak bagi kesehatan maupun dampak sosial. Dampak negatif bagi kesehatan terjadi sejak anak pada masa embrio hingga prasekolah. Sedangkan dampak sosial terjadi saat anak berusia prasekolah hingga dewasa, yaitu salah satunya terjadi transmisi perilaku merokok (Duhita \& Rahmawati, 2019). Maka tidak ada cara lain harus harus ada penegakan kebijakan pengendalian tembakau merupakan cara yang efektif untuk mengendalikan tembakau dan pada akhirnya mengurangi kebiasaan merokok (Farahdina et al., 2016), serta mengajarkan anak usia dini untuk menjaga kebersihan dan menjauhi asap rokok (Anhusadar \& Islamiyah, 2020). Masa kanak-kanak ini disebut masa keemasan (golden age) karena pada masa ini sel-sel otak pada anak berkembang sangat cepat hingga $80 \%$. Perkembangan yang luar biasa ini mencakup perkembangan fisik dan psikologis.

Dari segi fisik, anak mengalami perkembangan yang luar biasa, diawali dengan perkembangan motorik kasar seperti berjalan, berlari, melompat, dan memanjat, seiring dengan tumbuhnya sel-sel otak dan organ tubuh lainnya (Ulpi et al., 2021). Perkembangan yaitu bertambahnya kemampuan (skill) pada anak dalam struktur dan fungsi tubuh yang lebih kompleks dalam pola yang teratur dan dapat diramalkan, sebagai hasil dari proses pematangan. Perkembangan menyangkut adanya proses diferensiasi dari sel-sel tubuh, organ-organ, dan sistem organ, termasuk perkembangan emosi, intelektual, dan tingkah laku sebagai hasil interaksi dengan lingkungan (Husnuzziadatul Khairi, 2018), moral sebagai ukuran baik dan buruk (Abidin, 2021), yang dapat dirumuskan sebagai jalan yang harus diikuti orang untuk mencapai tujuan yang suci dan mulia (Ananda, 2017).

Perkembangan anak berlangsung secara bertahap (gradual), sistematis dan berkesinambungan. Perkembangan pada setiap orang adalah sama, hanya perbedaan laju perkembangannya, dan pada kenyataannya perubahan antara satu aspek dengan aspek lainnya terjadi secara bersamaan, tetapi ada peristiwa yang mendahului yang sebelumnya (Khaironi, 2018). Pertumbuhan dan perkembangan anak usia dini perlu diarahkan pada peletakan dasar-dasar yang tepat bagi pertumbuhan dan perkembangan manusia seutuhnya (Ariyanti, 2016). Hal ini dapat diperkuat oleh hasil penelitian yang membuktikan bahwa 
pemberian pendidikan sejak dini sangatlah penting karena akan mempengaruhi perkembangan otak anak, kesehatan anak, kesiapan anak bersekolah, kehidupan sosial dan ekonomi yang lebih baik dimasa selanjutnya, jika dibandingkan dengan anak-anak yang kurang terdidik pada usia dini (Rahmatia et al., 2021; Wulandari \& Purwanta, 2020), termasuk konten kurikulum harus benar dan berhubungan dengan seni, keindahan, dan keselarasan yang mengarah pada kebahagiaan dalam kehidupan anak di sesuai dengan akar budaya dimana dia tinggal dan nilai-nilai agama yang dianutnya (Duriani et al., 2021). Dengan konten berbasis keagamaan/ke-Islaman berfungsi secara tidak langsung mendidik mereka untuk rajin beribadah atau mengamalkan nilai-nilai keislaman (Wijaya et al., 2020).

Pendidikan moral pada anak merupakan pendidikan yang harus dimiliki oleh anak sejak dini. Pendidikan moral sejak dini akan membekali anak dengan moralitas seumur hidupnya saat berinteraksi dengan orang lain. Oleh karena itu, pendidikan moral pada anak sangatlah penting untuk usia anak usia dini, sehingga dibutuhkan pengasuhan tersendiri agar anak tumbuh menjadi cerdas dan memiliki budi pekerti (Khaironi, 2017) (Pagarwati \& Rohman, 2020). Menurut Syiaodih menyatakan bahwa perkembangan nilai agama dan moral anak usia dini yaitu: anak bersikap imitasi yakni anak telah mampu menirukan sikap, cara pandang serta tingkah laku orang lain, anak bersikap internalisasi yakni anak hendak bergaul dengan lingkungan sosialnya dan mulai terpengaruh oleh lingkungan sekitarnya, anak bersikap introvert dan ekstrovert yakni raksi yang ditujukkan anak berdasarkan pengalaman (Safitri et al., 2019).

Studi ini telah memiliki perbedaan dengan penelitian sebelumnya, dan kontribusi penting karena dilakukan di daerah yang telah menerapkan gaya hidup tanpa merokok dan telah menjadi komunal secara budaya dan agama. Selain itu, responden dari daerah lain yang tingkat merokoknya masih tinggi juga menghindari rokok yang merupakan salah satu penyebab penyakit yang dapat menghambat tumbuh kembang anak. Tujuan penelitian ini adalah melihat hubungan Lifestyle Without Tobacco terhadap perkembangan anak usia dini.

\section{METODOLOGI}

Penelitian ini dilakukan di desa Bone-Bone kecamatan Baraka kabupaten Enrekang, sebagai daerah di kaki gunung Latimojong dengan tingkat prevalensi perokok nol persen. Desa BoneBone adalah sebuah desa terpencil di kawasan pegunungan Latimojong Kabupaten Enrekang, Provinsi Sulawesi Selatan. Desa BoneBone masuk di wilayah kecamatan Baraka dengan luas 19,16 hektar, Baraka yang meliputi 3 dusun diantaranya dusun Bungin Bungin, dusun Buntu Billa dan dusun Pendokesan. Letak geografis desa Bone-Bone berada di wilayah selatan Kabupaten Enrekang. Letaknya di Kecamatan Baraka, berjarak sekitar $18 \mathrm{Km}$ dari Kecamatan Baraka sedangkan jarak dari bu kota Enrekang sekitas $59 \mathrm{Km}$. Desa ini telah memiliki Peraturan Desa nomor 1 Tahun 2009 tentang Kawasan Bebas Asap Rokok. Salah satu inovasi yang diusung oleh pemerintah Desa Bone-Bone untuk pendidikan dan pembangunan desa untuk kesejahteraan masyarakat adalah pembentukan desa bebas rokok untuk menciptakan lingkungan yang sehat. Masyarakat desa dan siapa pun yang berkunjung ke desa dilarang untuk merokok, menjual, atau sekadar memasang iklan rokok di poster atau bentuk lain di kawasan Desa Bone Bone.

Jenis penelitian ini adalah kuantitatif dengan menggunakan desain korelasional. Studi korelasi bertujuan untuk mengidentifikasi korelasi antar variabel (Pebruanti \& Munadi, 2015). Pendekatan yang digunakan dalam penelitian ini adalah pendekatan crossover yaitu 40 orang dari Desa Bone Bone, jenis penelitian dalam penelitian ini. Kriteria inklusi dalam penelitian ini adalah orang tua bayi dan balita yang tidak mengganggu komunikasi dan responden yang diinginkan.

Teknik dalam pengambilan sampel penelitian ini ini adalah purposive sampling. Purposive sampling adalah teknik penentuan sampel dengan pertimbangan tertentu (Sugiyono, 2015). Adapun langkah-langkah untuk mengambil subjek yang menjadi sampel ini 
dilakukan dengan cara; (i) menentukan kepala rumah tangga yang tidak merokok dan memiliki anak usia dini; (ii) menentukan subyek yang akan dijadikan responden/informan penelitian. Adapun prosedur dan tahapan penelitian ini ditampilkan pada gambar 1 .

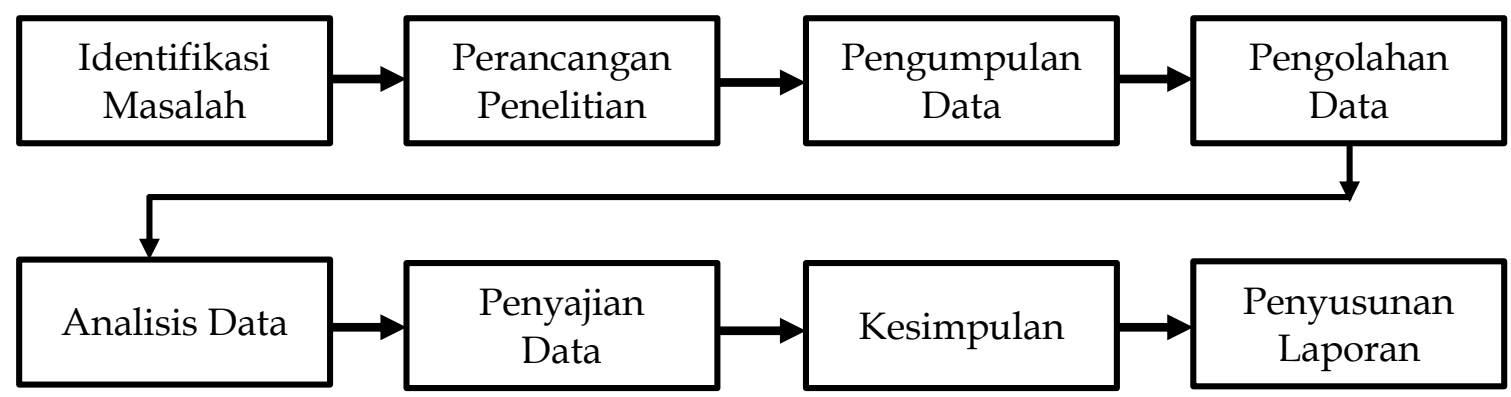

Gambar 1. Prosedur dan Tahapan Penelitian

Jika data yang diperoleh dari hasil pengumpulan dianalisis secara satu dimensi, maka dapat disajikan dalam bentuk distribusi frekuensi. Analisis dua dimensi dilakukan pada dua variabel yang dinilai berhubungan atau berkorelasi, dan peneliti menggunakan uji regresi logistik sederhana.

\section{HASIL DAN PEMBAHASAN}

\section{Perilaku Lifestyle Without Tobacco}

Desa Bone-Bone merupakan kawasan telah ditetapkan sebagai kawasan bebas tanpa rokok yang harus dipatuhi oleh masyarakat setempat. Menurut tanggapan dari masyarakat desa Bone-Bone mengatakan bahwa merokok dapat menyebabkan ketergantungan sehingga dapat merusak pola hidup sehat di lingkungan sekitar. Menerapkan pola hidup sehat memiliki beberapa tujuan contohnya; untuk kesehatan jasmani dan rohani dapat terjaga, dan juga dapat memiliki kesehatan mental yang stabil sehingga tidak mudah depresi ataupun setres (MI, Wawancara). Selain terkait dengan kesehatan pola hidup tanpa asap rokok masalah ekonomi juga sangat mempengaruhi kehidupan masyakat tersebut, dari wawancara masyarakat Desa Bone-Bone mengatakan bahwa kami di desa ini tidak mengonsumsi rokok karena selain merusak keshatan juga sangat mempengaruhi ekonomi, kami lebih memilih menggunakan uang tersebut untuk pendidikan anak-anak kami dan memperbanyak lahan pertanian. Di desa Bone-Bone sebagian besar anak-anaknya keluar desa untuk menuntut ilmu dan sukses di perantauan kemudian mereka kembali untuk membangun desa terutama membangun sebuah Pesantren di desa agar pendidikan agama anak lebih diutamakan.

Peran agama juga sangat penting dan dapat mereduksi konsumsi rokok di Indonesia. Hal ini dapat disamakan dengan peran agama dalam mengharamkan minuman keras, sehingga secara signifikan perilaku minuman keras di Indonesia tidak berkembang di pemeluk agama Islam (Pradhana, 2019). Secara ilmu pengetahuan, kesehatan, rokok merupakan barang yang berpotensi untuk membuat kondisi pemakainya justru menurun. Hal ini dapat diartikan bahwa merokok adalah kebiasaan yang tidak baik serta dilarang oleh Allah SWT. Demikian hal itu pendidik/orang tua harus menanamkan pada anak sejak dini bahwa bahaya dan dampak merokok itu sangatlah berbahaya, bukan hanya dari segi kesehatan jasmani dan rohani. Namun juga dapat merusak perkembangan pada anak sehingga menghambat perkembangan terutama pada perkembangan agama dan moral pada anak usia dini. Karakteristik responden yang tersebar pada desa Bone-Bone dan Desa Salukanan sebagai kontrol disajikan pada tabel 1.

Tabel 1. Karakteristik responden

\begin{tabular}{ccc}
\hline Karakteristik & Frekuensi & $\begin{array}{c}\text { Persentase } \\
\text { Responden }\end{array}$ \\
\hline
\end{tabular}




\begin{tabular}{lcc}
\hline Umur & & \\
3 tahun & 5 & 12,5 \\
4 tahun & 20 & 50,0 \\
5 tahun & 15 & 37,5 \\
Total & 40 & 100,0 \\
\hline Jenis kelamin & & \\
Laki-laki & 14 & 35,0 \\
Perempuan & 26 & 65,0 \\
Total & 40 & 100,0 \\
\hline Domisili (Alamat) & \\
Desa Bone-bone (KTR) & 20 & 50,0 \\
Desa Salukanan (Non KTR) & 20 & 50,0 \\
Total & 40 & 100,0 \\
\hline \multicolumn{2}{c}{ Sumber: data primer }
\end{tabular}

Berdasarkan tabel 1. tentang karakteristik responden menurut umur menunjukkan bahwa dari 40 jumlah responden, umur anak 3 tahun sebanyak 5 orang (12,5\%), umur anak 4 tahum sebanyak 20 orang (50\%) dan umur anak 5 tahun sebanyak 15 orang (37,5\%). Menurut jenis kelamin, laki-laki sebanyak 14 orang (35\%) dan perempuan sebanyak 26 orang (65\%). Sedangkan menurut domisili (alamat tempat tinggal), desa bone-bone sebagai desa yang mengimplementasikan KTR sebanyak 20 orang (50\%) dan desa salukanan sebagai desa pembanding/kontrol (non KTR) sebanyak 20 orang (50\%). Perilaku merokok pada desa BoneBone dan Desa Salukanan sebagai kontrol diuraikan pada tabel 2.

Tabel 2. Perilaku merokok

\begin{tabular}{lcc}
\hline Perilaku merokok & $\begin{array}{c}\text { Frekuensi } \\
\text { (F) }\end{array}$ & $\begin{array}{c}\text { Persentase } \\
(\mathbf{\%})\end{array}$ \\
\hline Merokok & 10 & 25,0 \\
Tidak merokok & 30 & 75,0 \\
Total & 40 & 100,0 \\
\hline \multicolumn{2}{c}{ Sumber: data primer }
\end{tabular}

Berdasarkan tabel 2. tentang perilaku merokok menyatakan bahwa dari 40 jumlah responden, sebanyak 30 orang ( $75 \%$ ) yang tidak merokok dan sebanyak 10 orang (25\%) yang merokok. Sementara itu perbandingan jumlah perokok berdasarkan domisili diuraikan pada tabel 3 .

Tabel 3. Perilaku merokok berdasarkan domisili

\begin{tabular}{lcc}
\hline Perilaku merokok berdasarkan domisili & $\begin{array}{c}\text { Frekuensi } \\
(\mathbf{F})\end{array}$ & $\begin{array}{c}\text { Persentase } \\
\mathbf{( \% )}\end{array}$ \\
\hline Desa Bone-bone & 0 & 0,0 \\
Merokok & 20 & 100,0 \\
Tidak merokok & $\mathbf{2 0}$ & $\mathbf{1 0 0 , 0}$ \\
Total & & \\
\hline Desa Salu kanan & 10 & 50,0 \\
Merokok & 10 & 50,0 \\
Tidak merokok & $\mathbf{2 0}$ & $\mathbf{1 0 0 , 0}$ \\
Total & Sumber: data primer
\end{tabular}

Berdasarkan tabel 3. tentang perilaku merokok berdasarkan domisili menyatakan bahwa dari 20 jumlah responden pada masing-masing daerah, sebanyak 20 orang (100\%) yang tidak merokok pada desa bone-bone. Sedangkan pada desa salukanan sebanyak 10 orang $(50 \%)$ yang tidak merokok dan sebanyak sebanyak 10 orang $(50 \%)$ yang merokok. 


\section{Perkembangan Anak Usia Dini}

Setiap anak tumbuh dan berkembang secara berbeda, bergantung dari pola asuh orang tua dan lingkungan sekitarnya. Meski begitu, anak-anak umumnya mencapai titik penting dalam kehidupan mereka di waktu yang bersamaan. Dalam Pedoman Pelaksanaan Stimulasi, Deteksi dan lntervensi Dini Tumbuh Kembang Anak (KPSP), perkembangan anak dapat dideteksi dengan Kuisioner Pra-Skrining Perkembangan (KPSP) yang diterbitkan oleh Kementerian Kesehatan. Interpretasi dari perkembangan anak dapat dikategorikan menjadi tiga; normal (S), meragukan (M), dan penyimpangan (P). Perkembangan anak usia dini pada desa Bone-Bone dan Salukanan disajikan pada tabel 4.

Tabel 4. Perkembangan Anak pada desa Bone-Bone dan Salukanan

\begin{tabular}{lcc}
\hline Perkembangan anak & $\begin{array}{c}\text { Frekuensi } \\
(\mathbf{F})\end{array}$ & $\begin{array}{c}\text { Persentase } \\
\mathbf{( \% )}\end{array}$ \\
\hline Normal & 30 & 75,0 \\
Meragukan & 9 & 22,5 \\
Meyimpang & 1 & 2,5 \\
Total & 40 & 100,0 \\
\hline \multicolumn{3}{c}{ Sumber: data primer }
\end{tabular}

Berdasarkan tabel 4. tentang perkembangan anak menyatakan bahwa dari 40 jumlah responden, sebanyak 30 orang (75\%) perkembangan yang normal, sebanyak 9 orang $(22,5 \%)$ yang meragukan dan 1 orang (2,5\%) yang menyimpang. Secara umum, data dari desa BoneBone dan Salukanan menunjukkan perkembangan anak usia dini mayoritas berada pada kategori normal. Tahap selanjutnya adalah perbandingan antara kedua desa yang menerapkan kawasan tanpa rokok dan belum menerapkan kawasan tanpa rokok. Perbandingan perilaku merokok pada dua desa disajikan pada tabel 5.

Tabel 5. Perbandingan Perilaku Merokok Berdasarkan Domisili

\begin{tabular}{|c|c|c|c|c|c|c|c|c|c|}
\hline \multirow{3}{*}{ Perilaku Merokok } & \multicolumn{6}{|c|}{ Perkembangan Anak Usia Dini } & \multirow{2}{*}{\multicolumn{2}{|c|}{ Total }} & \multirow[t]{3}{*}{$\rho$} \\
\hline & \multicolumn{2}{|c|}{ Normal } & \multicolumn{2}{|c|}{ Meragukan } & \multicolumn{2}{|c|}{ Menyimpang } & & & \\
\hline & $\mathbf{N}$ & $\%$ & $\mathbf{n}$ & $\%$ & $\mathbf{n}$ & $\%$ & $\mathbf{N}$ & $\%$ & \\
\hline \multicolumn{10}{|l|}{ Desa Bone-bone } \\
\hline Merokok & 0 & 0,0 & 0 & 0,0 & 0 & 0,0 & 0 & 100 & Constant* \\
\hline Tidak Merokok & 19 & 95,0 & 1 & 5,0 & 0 & 0,0 & 20 & 100 & \\
\hline Total & 19 & 95,0 & 1 & 5,0 & 20 & 2,5 & 20 & 100 & \\
\hline \multicolumn{10}{|l|}{ Desa Salukanan } \\
\hline Merokok & 2 & 10,0 & 7 & 35,0 & 1 & 5,0 & 10 & 50,0 & \\
\hline Tidak Merokok & 8 & 40,0 & 2 & 10,0 & 0 & 0,0 & 10 & 50,0 & $0,000^{*}$ \\
\hline Total & 10 & 50,0 & 9 & 45,0 & 1 & 5,0 & 20 & 100 & \\
\hline
\end{tabular}

Berdasarkan tabel 5. menyatakan bahwa dari 40 jumlah responden pada masingmasing desa menunjukkan bahwa pada desa bone-bone sebagai desa yang mengimplementasikan KTR, diperoleh sebanyak 19 orang $(95 \%)$ yang memiliki orang tua tidak merokok dengan perkembangan anak normal dan 1 orang (5\%) yang memiliki orang tua tidak merokok dengan perkembangan anak meragukan. Sedangkan pada desa salukanan sebagai desa yang tidak mengimplementasikan KTR, diperoleh sebanyak 2 orang (10\%) yang memiliki orang tua merokok dengan perkembangan anak normal, sebanyak 7 orang (35\%) yang memiliki orang tua merokok dengan perkembangan anak meragukan dan 1 orang $(5 \%)$ yang memiliki orang tua merokok dengan perkembangan anak menyimpang. Selanjutnya, sebanyak 8 orang (40\%) yang memiliki orang tua tidak merokok dengan perkembangan anak 
yang normal, sebanyak 2 orang anak $(10,0 \%)$ yang memiliki orang tua tidak merokok dengan perkembangan anak meragukan dan tidak ada yang memiliki orang tua tidak merokok dengan perkembangan anak menyimpang.

Berdasarkan hasil uji chi-square diperoleh nilai $\rho=0,000<$ nilai $\alpha=0,05$. Hal ini berarti ada ada ada perbedaan antara antara desa yang mengimplementasikan KTR dan non KTR terhadap pekembangan anak usia dini. Setiap individu mengalami perkembangan. Perkembangan terjadi sejak bayi hingga dewasa. Perkembangan tidak dapat diukur, tetapi dapat dirasakan. Perkembangannya bertahap (gradual), sistematis dan berkesinambungan. Apa yang berkembang pada setiap orang adalah sama (Khaironi, 2018), hanya perbedaan laju perkembangannya, dan pada kenyataannya perubahan antara satu aspek dengan aspek lainnya terjadi secara bersamaan, tetapi ada peristiwa yang mendahului yang sebelumnya.

\section{Hubungan dan Kontribusi Perilaku Lifestyle Without Tobacco}

Perilaku merokok dalam banyak teori dapat memberikan dampak buruk terhadap kesehatan manusia, khususnya perkembangan anak usia dini. Hal ini sangat penting untuk diantisipasi, mengingat anak usia dini membutuhkan lingkungan yang sehat dan layak bagi perkembangannya. Jika lingkungannya tidak mendukung, maka perkembangan anak dapat terhambat. Hubungan Lifestyle Without Tobacco terhadap perkembangan anak usia dini dapat dilihat pada tabel 6 .

Tabel 6. Hubungan Lifestyle Without Tobacco Terhadap Perkembangan Anak Usia Dini

\begin{tabular}{|c|c|c|c|c|c|c|c|c|c|}
\hline \multirow{3}{*}{ Perilaku Merokok } & \multicolumn{6}{|c|}{ Perkembangan Anak Usia Dini } & \multirow{2}{*}{\multicolumn{2}{|c|}{ Total }} & \multirow[t]{3}{*}{$\rho$} \\
\hline & \multicolumn{2}{|c|}{ Normal } & \multicolumn{2}{|c|}{ Meragukan } & \multicolumn{2}{|c|}{ Menyimpang } & & & \\
\hline & $\mathbf{n}$ & $\%$ & $\mathbf{n}$ & $\%$ & $\mathbf{n}$ & $\%$ & $\mathbf{N}$ & $\%$ & \\
\hline $\mathrm{Ya}$ & 2 & 5,0 & 7 & 17,5 & 1 & 2,5 & 10 & 25,0 & $0,00^{*}$ \\
\hline Tidak & 29 & 70,0 & 2 & 5,0 & 0 & 0,0 & 30 & 75,0 & \\
\hline Total & 30 & 75,0 & 9 & 22,5 & 1 & 2,5 & 40 & 100 & \\
\hline
\end{tabular}

Berdasarkan tabel 6. menyatakan bahwa dari 40 jumlah responden sebanyak 2 orang (5\%) yang memiliki orang tua merokok dengan perkembangan anak yang normal, sebanyak 7 orang $(17,5 \%)$ yang meragukan dan sebanyak 1 orang $(2,5 \%)$ yang menyimpang. Sedangkan sebanyak 28 orang (70\%) yang memiliki orang tua tidak merokok dengan perkembangan anak yang normal, sebanyak 2 orang anak $(5,0 \%)$ yang memiliki orang tua tidak merokok dengan perkembangan anak meragukan dan tidak ada yang memiliki orang tua tidak merokok dengan perkembangan anak menyimpang. Berdasarkan hasil uji chi-square diperoleh nilai $\rho$ $=0,000<$ nilai $a=0,05$. Hal ini berarti ada ada hubungan perilaku merokok dengan perkembangan anak usia dini. Sedangkan kontribusi kontribusi lifestyle without tobacco terhadap perkembangan anak usia dini disajikan pada tabel 7.

Berdasarkan hasil uji regresi logistik sederhana diperoleh bahwa nilai Exp (B) 56,0 dan nilai $\rho=0,000$. Hal ini berarti bahwa Lifestyle Without Tobacco memiliki peluang 56 kali terhadap perkembangan anak normal (sesuai dengan usianya). Adanya kontribusi yang kuat antara pola hidup tanpa tembakau dengan perkembangan anak usia dini harus diimplementasikan dalam bentuk peraturan baik secara formal maupun informal pada seluruh kawasan di Indonesia. Pemerintah memiliki target untuk menurunkan angka prevalensi perokok yang sampai saat ini masih sangat tinggi.

Tabel 7. Kontribusi Lifestyle Without Tobacco Terhadap Perkembangan Anak Usia Dini 


\begin{tabular}{|c|c|c|c|c|c|c|c|c|}
\hline & \multirow[b]{2}{*}{ B } & \multirow[b]{2}{*}{ S.E. } & \multirow[b]{2}{*}{ Wald } & \multirow[b]{2}{*}{ Sig. } & \multirow[b]{2}{*}{$\operatorname{Exp}(B)$} & \multicolumn{2}{|c|}{ 95\% C.I.for EXP(B) } \\
\hline & & & & & & & Lower & Upper \\
\hline \multirow[t]{2}{*}{ Step $1^{a}$} & Perilaku merokok (1) & 4,025 & 1,077 & 13,960 & 1,000 & 56,000 & 6,779 & 462,639 \\
\hline & Constant & $-2,639$ & ,732 & 13,001 & 1,000 & ,071 & & \\
\hline
\end{tabular}

a. Variable(s) entered on step 1: Perilaku merokok.

**uji regresi logistik sederhana

Hasil penelitian ini menunjukkan bahwa ada perbedaan perkembangan anak usia dini pada wilayah yang telah dan belum menerapkan kawasan tanpa rokok, serta ada hubungan antara perilaku lifestyle without tobacco dengan perkembangan anak usia dini. Dari 40 jumlah responden pada dua desa yang menerapkan dan tidak menerapkan kawasan tanpa rokok terdapat perbedaan data perkembangan anak (lihat tabel 4 dan 5). Hasil uji chi-square diperoleh nilai $\rho=0,000<$ nilai $\alpha=0,05$. Hal ini berarti ada ada ada perbedaan antara antara desa yang mengimplementasikan KTR dan non KTR terhadap pekembangan anak usia dini. Setiap individu mengalami perkembangan. Sejalan dengan penelitian mengenai perkembangan anak (Sumiyati \& Yuliani, 2016) Perlu dilakukan pendidikan kesehatan kepada ibu-ibu anak usia dini tentang pemberian stimulasi untuk merangsang kemampuan dasar anak yang meliputi kemampuan motorik kasar, motorik halus, bicara-bahasa dan sosialisasikemandirian berkaitan yang dengan perkembangan anak. Tenaga kesehatan dan kader diharapkan mengoptimalkan deteksi dan intervensi dini tumbuh kembang pada anak usia dini. Sedangkan pada penelitian (Aksol \& Sodik, 2021) mengatakan Kandungan zat kimia yang terdapat dalam rokok sangat berbahaya bagi kesehatan terutama bagi anak usia dini yang dapat berpengaruh pada otak, mulut dan tenggorokan, paru-paru, lambung serta kulit. Hampir seluruh warga negara Indonesia baik itu dewasa, orang tua, dan remaja membudayakan merokok sebagai penunjang aktivitas atau kebiasaan, sedangkan merokok memiliki dampak yang sangat banyak terhadap berbagai macam penyakit yang dapat menyerang orang yang merokok itu maupun.

Sementara itu, kontribusi lifestyle without tobacco berdasarkan hasil uji regresi logistik sederhana diperoleh nilai Exp (B) 56,0 dan nilai $\rho=0,000$, yang diinterpretasikan bahwa Lifestyle Without Tobacco memiliki peluang 56 kali terhadap perkembangan anak normal (lihat tabel 7). Adanya kontribusi yang kuat antara pola hidup tanpa tembakau dengan perkembangan anak usia dini harus diimplementasikan dalam bentuk peraturan baik secara formal maupun informal pada seluruh kawasan di Indonesia. Dalam penelitian (Rahman, 2009) mengatakan dalam perkembangan anak disertai dengan karakteristik-karakteristik yang meilputi aspek motorik, lalu aspek kognitif, aspek social emosional dan aspek bahasa. Semuanya memegang peranan dalam membantu keberhasilan anak belajar, sebab jika terjadi disfungsi perkembangan anak akan mengalami kesulitan belajar. Hal ini didukung oleh penelitian (Pranungsari et al., 2021) berkaitan dengan program head start. Program Head Start adalah program untuk anak usia dini dari kalangan kelas ekonomi bawah oleh pemerintah Amerika, yang mengharuskan orang tua berpartisipasi dan terlibat dalam program, sehingga program harus dijalankan oleh orang tua. Sedangkan penelitian (Margiyati, 2016) faktor penyebab terjadinya ketuban pecah dini terdapat beberapa faktor yang dapat mempengaruhi terjadinya ketuban pecah dini yaitu: capek, rokok, dan infeksi genetalia. Dengan demikian, sudah waktunya pemerintah dari berbagai level menyiapkan kawasan bebas asap rokok agar menjadi daerah yang layak untuk perkembangan anak usia dini.

\section{SIMPULAN}

Hasil analisis data ditemukan adanya hubungan antara lifestyle without tobacco dengan perkembangan anak usia dini. Semakin kecil prevalensi perokok, maka semakin baik potensi 
perkembangan anak pada derah tersebut. Pada kawasan yang menerapkan kawasan tanpa asap rokok perkembangan anak usia dini lebih baik dibandingkan dengan desa yang tidak menerapkan kawasan tanpa asap rokok. Hal ini sangat penting untuk menjadi agenda bersama terutama pemerintah untuk segera melakukan langkah nyata dalam menerapkan kawasan tanpa rokok, mengingat anak usia dini sangat membutuhkan lingkungan yang sehat dan layak bagi perkembangannya.

\section{UCAPAN TERIMA KASIH}

Puji dan syukur peneliti panjatkan kepada Allah Swt. atas segala rahmat dan karuniaNya yang telah memberikan kesehatan dan kesempatan pada peneliti sehingga riset ini dapat diselesaikan dengan baik. Kepada Lembaga Pengelola Dana Pendidikan (LPDP) yang telah memfasilitasi tim peneliti dalam program Riset Keilmuan 2021, dan mahasiswa menjadi peserta dalam program tersebut sebagai bagian dari implementasi Merdeka Belajar Kampus Merdeka. Atas segala kekurangan baik secara teknis maupun subtansi dalam penelitian ini akan disempurnakan di masa yang akan datang.

\section{DAFTAR PUSTAKA}

Abidin, A. M. (2021). Pendidikan Moral dan Relevansinya dengan Pendidikan Islam. Jurnal Paris Langkis, 2(1), 57-67. https:// doi.org/10.37304/paris.v2i1.3282.

Aksol, M. I. M., \& Sodik, M. A. (2021). Bahaya Merokok Bagi Masa Depan dan Kesehatan. https://doi.org/10.31219/osf.io/eg6xy.

Ananda, R. (2017). Implementasi Nilai-nilai Moral dan Agama pada Anak Usia Dini. Jurnal Obsesi : Jurnal Pendidikan Anak Usia Dini, 1(1), 19. https://doi.org/10.31004/obsesi.v1i1.28.

Anhusadar, L., \& Islamiyah, I. (2020). Penerapan Perilaku Hidup Bersih dan Sehat Anak Usia Dini di Tengah Pandemi Covid 19. Jurnal Obsesi : Jurnal Pendidikan Anak Usia Dini, 5(1), 463. https://doi.org/10.31004/obsesi.v5i1.555.

Ariyanti, T. (2016). The Importance of Childhood Education for Child Development. Dinamika Pendidikan Dasar, 8(1), 50-58.

Duhita, F.-, \& Rahmawati, N. I. (2019). Dampak Kesehatan Anak Pada Periode Embrio, Janin, Bayi dan Usia Sekolah dengan Ayah Perokok. Jurnal Kesehatan Vokasional, 4(1), 12. https:// doi.org/10.22146/jkesvo.41777.

Duriani, D., Rama, B., Pajarianto, H., \& Sari, P. (2021). Thematic Learning in Kindergarten Based on Al-Islam Kemuhamadiyahan and Local Wisdom. Jurnal Obsesi : Jurnal $\begin{array}{llll}\text { Pendidikan Anak Usia 2220-2230. } & \text { 5(2), }\end{array}$ https://doi.org/10.31004/obsesi.v5i2.1171.

Evi Hasnita, Nurhayati, O. (2021). Pemberdayaan kader pbhs dalam memberikan edukasi tentang bahaya merokok di nagari koto tangah baso. Empowering Society Journal, 2(1), 50-58. https:// doi.org/10.30590/jach.v2n2.316.

Farahdina, S., Cahyo, K., \& Riyanti, E. (2016). Analisis Implementasi Peraturan Daerah Kota Semarang Nomor 3 Tahun 2013 Tentang Kawasan Tanpa Rokok di Kantor Kelurahan Kota Semarang. Jurnal Kesehatan Masyarakat (Undip), 4(3), 1096-1103.

Hasibuan, R. L., \& Harahap, P. S. (2019). Implementasi Peraturan Daerah Kota Medan No. 3 Tahun 2014Tentang Kawasan Tanpa Asap Rokok Pada Kota Medan. Jurnal Hukum Responsif, 7(7), 96-101.

Husnuzziadatul Khairi. (2018). Karakteristik Perkembangan Anak Usia Dini dari 0-6 Tahun. Jurnal Warna, 2(2), 15-28.

Khaironi, M. (2017). Pendidikan Moral Pada Anak Usia Dini. Jurnal Golden Age, 1(01), 1. https:// doi.org/10.29408/goldenage.v1i01.479.

Khaironi, M. (2018). Perkembangan Anak Usia Dini. Jurnal Golden Age, 2(01), 01. https:// doi.org/10.29408/goldenage.v2i01.739. 
Margiyati, D. A. I. (2016). Dampak Paparan Asap Rokok Pada Ibu Bersalin Dengan Riwayat Ketuban Pecah Dini. Jurnal Ilmu Kebidanan, 1-6.

Muhammad Amin Rais, A. S. F. (2021). Studi Kasus Perdes Bebas Asap Rokok di Desa Bonebone, Kab. Enrekang. Journal Unhas, 1(1), 32-50.

Munthe, V. I. G. dan R. (2018). Terhadap Pengetahuan Bahaya Asap Rokok Anak Usia Dini (Paud) Di Kelurahan Dwikora Kecamatan Medan. Jurnal Kesmas Indonesia, 10(2), 149162.

Pagarwati, L. D. A., \& Rohman, A. (2020). Grandparenting Membentuk Karakter Anak Usia Dini di Masa Pandemi Covid-19. Jurnal Obsesi : Jurnal Pendidikan Anak Usia Dini, 5(2), 1229-1239. https://doi.org/10.31004/obsesi.v5i2.831.

Pebruanti, L., \& Munadi, S. (2015). Peningkatan Motivasi Dan Hasil Belajar Pada Mata Pelajaran Pemograman Dasar Menggunakan Modul Di Smkn 2 Sumbawa. Jurnal Pendidikan Vokasi, 5(3), 365. https://doi.org/10.21831/jpv.v5i3.6490.

Pradhana, R. A. (2019). Pradhana, R. A. (2019). Rokok dalam Aspek Sosial-Agama Masyarakat Indonesia. Journal of Islamicate Multidisciplinary, 4(2).

Pranungsari, D., Tarnoto, N., \& Tentama, F. (2021). Pelatihan "Great Mom Great Children" pada Ibu Muda Jalanan dalam Meningkatkan Ketrampilan Stimulasi Perkembangan Anak. Jurnal Obsesi: Jurnal Pendidikan Anak Usia Dini, 6(2), 1126-1134. https://doi.org/10.31004/obsesi.v6i2.1161.

Rahman, U. (2009). Karakteristik Perkembangan Anak Usia Dini. Lentera Pendidikan : Jurnal Ilmu Tarbiyah Dan Keguruan, 12(1), 46-57. https://doi.org/10.24252/lp.2009v12n1a4.

Rahmatia, R., Pajarianto, H., Kadir, A., Ulpi, W., \& Yusuf, M. (2021). Pengembangan Model Bermain Konstruktif dengan Media Balok untuk Meningkatkan Visual-Spasial Anak. Jurnal Obsesi: Jurnal Pendidikan Anak Usia Dini, 6(1), 47-57. https://doi.org/10.31004/obsesi.v6i1.1185.

Safitri, N., Kuswanto, C. W., \& Alamsyah, Y. A. (2019). Metode Penanaman Nilai-Nilai Agama Dan Moral Anak Usia Dini. Journal of Early Childhood Education (JECE), 1(2), 29-44. https://doi.org/10.15408/jece.v1i2.13312.

Sugiyono. (2015). Metode penelitian kombinasi (mixed methods). Bandung: Alfabeta.

Sumiyati, \& Yuliani, D. R. (2016). Hubungan Stimulasi dengan Perkembangan Anak 4-5 Tahun di Desa Karang Tengah Kecamatan Baturraden Kabupaten Banyumas. Jurnal LINK, 12(1), 34-38. http:// ejournal.poltekkes-smg.ac.id/ojs/index.php/link

Ulpi, W., Hakim, N., Kadir, A., Pajarianto, H., \& Rahmatia, R. (2021). Gambaran Kebugaran Jasmani Anak Usia Dini pada Masa Pandemi Covid-19. Jurnal Obsesi: Jurnal Pendidikan Anak Usia Dini, 6(1), 30-39. https://doi.org/10.31004/obsesi.v6i1.1197.

Wijaya, C., Lubis, R. R., Haidir, H., Suswanto, S., \& Saputra, I. B. (2020). Program One Week One Story Berbasis Keislaman sebagai Bekal Keterampilan Abad 21 pada Anak Usia Dini. Jurnal Obsesi : Jurnal Pendidikan Anak Usia Dini, 5(2), 1544-1556. https://doi.org/10.31004/obsesi.v5i2.917.

Wulandari, H., \& Purwanta, E. (2020). Pencapaian Perkembangan Anak Usia Dini di Taman Kanak-kanak selama Pembelajaran Daring di Masa Pandemi Covid-19. Jurnal Obsesi : $\begin{array}{lllll}\text { Jurnal Pendidikan Anak Usia } & \end{array}$ https://doi.org/10.31004/obsesi.v5i1.626. 